Rok XIV (2019) | 2 (28) | s. 253-263

https://doi.org/10.12797/LV.14.2019.28.17

Maciej Grochowski ๑

Instytut Języka Polskiego Polskiej Akademii Nauk, Kraków

magro@umk.pl

\title{
POJĘCIE ZNACZENIA I JEGO ZAKRES W KONCEPCI SKŁADNI ZENONA KLEMENSIEWICZA ${ }^{1}$
}

Słowa klucze: Zenon Klemensiewicz, język polski, składnia, semantyka, znaczenie, językoznawstwo polskie XX w.

Keywords: Zenon Klemensiewicz, the Polish language, syntax, semantics, meaning, Polish linguistics in the $20^{\text {th }}$ century

1. W pierwszych trzech paragrafach tego artykułu przedstawiam rekonstrukcję poglądów Zenona Klemensiewicza na znaczenie obiektów językowych, którymi operuje uczony. Paragrafy czwarty i piąty zawierają przede wszystkim analizę i ocenę tych poglądów z punktu widzenia teorii syntaktycznych połowy XX w. Do podstawowych źródeł, na których się opieram, należą takie prace uczonego, jak O znaczeniu stosunkowym struktur składniowych (Klemensiewicz 1958/1969), Składnia opisowa współczesnej polszczyzny kulturalnej (Klemensiewicz 1937), Zarys składni polskiej (Klemensiewicz 1963a), Studia syntaktyczne (Klemensiewicz 1967, 1969a). Z perspektywy wielu dziesięcioleci, które minęły od ich powstania, nie da się traktować tych prac inaczej, niż jako dzieł o wartości historycznej, kształtujących rozwój językoznawstwa w Polsce w XX w., ważnych dokumentów epoki, w której powstały.

Z. Klemensiewicz nigdzie nie prezentował explicite, o ile mi wiadomo, swojej koncepcji znaczenia ani nie odwoływał się do teorii znaczenia innych uczonych,

1 Publikacja przygotowana w ramach projektu NPRH nr $11 \mathrm{H} 17$ 006685, realizowanego w latach 2018-2023. 
którą aprobował. W związku z tym przypisanie mu jakiejś ogólnej koncepcji znaczenia pozostanie na zawsze hipotezą. Za dopuszczalną można uznać, moim zdaniem, hipotezę, iż sposób podejścia Klemensiewicza do znaczenia wyrażeń jest bliski teoriom asocjacjonistycznym, wywodzącym się od empirystów brytyjskich, przede wszystkim od Johna Locke'a (1955). Przedstawienia, wyobrażenia, idee powiązane są u Locke’a z wyrażeniami językowymi na zasadzie skojarzeniowej. Myśl ta znajduje potwierdzenie $w$ literaturze $z$ zakresu filozofii języka (por. m.in. Ajdukiewicz 1960: 109-120; Dziobkowski 2016: 19-26; Grabarczyk 2018: 21-27; Maciaszek 2008: 87-93). Ślady takiego podejścia do opisu wyrażeń widoczne są u Klemensiewicza (1963a: 104) np. w charakterystyce wypowiedzenia zestawionego. Należące do niego wypowiedzenia

biegną niezależnie od siebie, każde swoim torem, ale ponieważ wskutek takiego czy innego skojarzenia zaczepiają o siebie myślowo, stanowią jednak całość i odrębny twór syntaktyczny.

Tak rozumiane wypowiedzenia zestawione zaliczano dawniej do stylistyki (Górny 1962: 192), dziś do gramatyki tekstu czy też do makroskładni (Żabowska 2017: 83).

Z. Klemensiewicz reprezentował nurt tradycyjny w składni polskiej, określany także jako przedstrukturalny, „zbliżony do zasad strukturalnych” czy humanistyczny (Lewicki 1971: 8, 2001: 636; Grochowski 2011). Teoria syntaktyczna uczonego, oparta $\mathrm{w}$ okresie międzywojennym na podstawach psychologicznych i filozoficznych (Klemensiewicz 1937), ewoluowała w kierunku badań funkcji komunikatywnej i poznawczej wypowiedzenia (Klemensiewicz 1963a), a w końcowym okresie rozwoju zmierzała metodologicznie w stronę deskryptywizmu (Klemensiewicz 1967, 1969a).

Kluczowymi terminami w koncepcji składni Klemensiewicza są wypowiedzenie i składnik (Zaron 2002; Grochowski 2011). Oba są definiowane jako znaki językowe odpowiednio powiadomienia i przedstawienia (szerzej Klemensiewicz 1937: 9, 44). Nosicielem znaczenia jest według uczonego (Klemensiewicz 1958/1969: 186) wyraz. $\mathrm{W}$ pracach składniowych terminem tym posługuje się on intuicyjnie, bez definicji, uważając, że badanie wyrazów, a tym samym ich znaczeń, należy do „nauki o znaczeniu i formie wyrazu", a nie do składni, zajmującej się związkami międzywyrazowymi (Klemensiewicz 1937: XIV-XV). Na potrzeby składni, w późniejszych pracach podręcznikowych, jedynie dzieli wyrazy na samodzielne i niesamodzielne. Pierwsze to

znaki myśli o przedmiotach (rzeczowniki oraz rzeczownikowe zaimki i liczebniki), o czynnościach i stanach (czasowniki), o właściwościach przedmiotów oraz czynności i stanów (przymiotniki, przymiotnikowe zaimki i liczebniki oraz niektóre przysłówki, zaimki i liczebniki przysłówkowe), o okolicznościach towarzyszących czynnościom, stanom lub właściwościom (niektóre przysłówki, zaimki i liczebniki przysłówkowe); [...] wchodzą one w stosunki syntaktyczne wymagane i wyznaczone sensem całości wypowiedzenia; 
drugie

nie są znakami myśli o przedmiotach, właściwościach, czynnościach, stanach i okolicznościach, ale stanowią znak ustosunkowania syntaktycznego wyrazów samodzielnych. Należą tu przede wszystkim przyimki i spójniki (Klemensiewicz 1963a: 19).

W swoich ostatnich pracach uczony nazywa je wypowiednikami pomocniczymi, inaczej wyznacznikami, i zalicza do nich również partykuły (Klemensiewicz 1967: 11), kwalifikowane we wszystkich wcześniejszych pracach jako składniki bądź wyznaczniki dodatkowe (Klemensiewicz 1963a: 26-28), niewchodzące w stosunki syntaktyczne z innymi składnikami (por. też Grochowski 2011: 51-53).

2. Mówiący rozumie wyraz, a także zależność międzywyrazową, w sposób indywidualny, łącząc je z myślami, które z nich wynikają. Wyrazy mają znaczenia leksykalne. Według Klemensiewicza (1958/1969: 189) znaczenie leksykalne wyrazu to „przyporządkowany mu sposób rozumienia w danym języku”. Przeciwstawia się ono znaczeniu obiektów wyższego rzędu, którymi zajmuje się składnia. Obiektami tymi są zespoły składników wypowiedzeń i wypowiedzenia, czyli struktury syntaktyczne. Zarówno między składnikami wypowiedzeń pojedynczych, jak i między wypowiedzeniami składowymi wypowiedzeń złożonych zachodzą związki semantyczne. Związek taki nazywa Klemensiewicz (ibid.: 186-189) „znaczeniem stosunkowym struktury składniowej”, zastępując niekiedy dwa ostatnie człony tego terminu określeniami „międzywyrazowe” („międzyskładnikowe”) lub „międzywypowiedzeniowe”. Oto jedna z proponowanych przez Klemensiewicza definicji terminu znaczenie stosunkowe:

przyporządkowany realizowanemu przez mówiącego w operacji wypowiedzeniotwórczej zespołowi albo wypowiedzeniu złożonemu sposób rozumienia wzajemnej zależności składników w tym zespole, albo dwu wypowiedzeń składowych w tym wypowiedzeniu złożonym (ibid.: 189).

Z. Klemensiewicz (ibid.: 199) postulował powstanie semantyki syntaktycznej, dyscypliny opartej m.in. na semantyce leksykalnej. Znaczenie stosunkowe miałoby należeć do zakresu badań semantyki syntaktycznej. Semantyka leksykalna natomiast, podporządkowana „nauce o znaczeniu i formie wyrazów”, nie stanowiła przedmiotu zainteresowań uczonego. Klemensiewicz twierdził co prawda, że znaczenie stosunkowe zależy [podkreślenie moje - M.G.] od znaczenia leksykalnego, ale nie wyjaśnił, na czym związek między tymi wielkościami polega i czym się one od siebie różnią.

Wykładnikami znaczenia stosunkowego, a więc środkami językowymi, za pomocą których jest ono realizowane, są (a) w obrębie stosunków międzywypowiedzeniowych spójniki, zaimki względne oraz odpowiedniki i zapowiedniki zespolenia w postaci zaimków wskazujących, (b) w obrębie stosunków międzyskładnikowych spójniki, przyimki i formy fleksyjne pozwalające na realizację składni zgody i rządu. 
W obu rodzajach stosunków istotny wpływ na wyrażane znaczenie mogą mieć szyk i czynniki prozodyczne (ibid.: 189-190). Uczony tej ostatniej tezy nie uzasadnia ani nie ilustruje jej żadnym przykładem. Wykładnikami znaczeń stosunkowych połączenia, przeciwstawienia i alternatywy, realizowanych przez przykładowe zespoły składników róża i fiołek; zdolny, ale leniwy; dziś albo jutro, są łączące je spójniki $i$, ale, lub. Przykład połączenia bezspójnikowego zimna woda Klemensiewicz rozumie „jako zespół, w którym treść składnika rzeczownikowego woda jest określona właściwością zawartą w treści składnika przymiotnikowego zimna" (ibid.: 188-189).

3. Celem badań, jaki sobie stawia Z. Klemensiewicz (ibid.: 191), nie jest opis wykładników znaczenia stosunkowego, byłoby to bowiem wieloletnie zadanie empiryczne dla dużego zespołu badawczego. Uczony chce przeprowadzić klasyfikację znaczeń stosunkowych, zhierarchizowaną i wyróżniającą ich podstawowe typy. Zdając sobie sprawę $\mathrm{z}$ tego, że jest to zadanie niezwykle trudne, rozróżnia jedynie stosunek współrzędności i niewspółrzędności (nadrzędno-podrzędny), a w obrębie tego drugiego stosunek orzekający i przyłączający. Jeżeli „podrzędnik jest ukształtowany językowo jako wyraz sądu o zdeterminowanym czasowo, przestrzennie i przejawowo istnieniu lub nieistnieniu nadrzędnika”, to "mamy do czynienia ze stosunkiem orzekającym", w pozostałych wypadkach ze stosunkiem przyłączającym. Jego funkcja polega na „zakreślaniu granicy nadrzędnika za pośrednictwem treści podrzędnika" (ibid.).

Klemensiewicz (ibid.: 192-193) zastanawia się, czy klasyfikacja znaczeń stosunkowych nie powinna być bardziej szczegółowa, a jeżeli tak, to w jaki sposób ją przeprowadzać, które cechy treściowe stosunków syntaktycznych są dla ich opisu istotne i na jakiej podstawie tę istotność ustalać, gdzie przebiega granica między znaczeniem leksykalnym a znaczeniem stosunkowym rozumianym w sposób ogólny jako znaczenie kategorialne. Te i inne pytania teoretyczno-metodologiczne uczony uważa za trudne i traktuje je jako otwarte.

Brak kryteriów klasyfikacji znaczeń stosunkowych jest przyczyną tego, że proponowana przez uczonego ich charakterystyka polega na wyliczeniu dwudziestu jeden typów (a w obrębie jednego z nich pięciu podtypów) stosunków. Nie ulega wątpliwości, że wyliczenie to można kontynuować w nieskończoność. Nawiązanie Klemensiewicza (ibid.: 198) do dziesięciu kategorii ontologicznych Arystotelesa (1975) wskazuje jedynie na najogólniejsze źródło wiedzy uczonego o znaczeniach struktur składniowych. Czerpie ją z ich odniesienia do świata pozajęzykowego. Klemensiewicz (1958/1969: 189) uważa znaczenie stosunkowe za „wytwór myśli, która przyobleka się w postać językową", z kolei w strukturze składniowej odbijają się według niego „różnorodne związki między komponentami odnośnego fragmentu rzeczywistości”. Uczony nie posługuje się co prawda rozpowszechnionym w językoznawstwie terminem znaczenie realne, ale trudno byłoby odrzucić hipotezę, że ustala znaczenia wyrażeń w wyniku ich konfrontacji z rzeczywistością. Z drugiej jednak strony nie 
traktuje referencji wyrażeń jako odrębnej, przysługującej im kategorii poznawczej. Obca mu była Fregego (1977) opozycja sensu i odniesienia (por. też Maciaszek 2008: 112-134; Grabarczyk 2018: 37-50).

Klemensiewicz (1958/1969: 193-198) nie mówi co prawda wprost, co stanowi przedmiot proponowanego przez niego podziału znaczeń stosunkowych, ale w świetle innych prac syntaktycznych uczonego przedmiot ten nie jest trudno ustalić. Podstawą klasyfikacji są ujęte globalnie znaczenia stosunkowe komunikowane zarówno przez zespół składników wypowiedzenia pojedynczego, jak i przez dwa wypowiedzenia składowe w wypowiedzeniu złożonym. Aby teza ta nie była gołosłowna, wymienię wyodrębnione przez Klemensiewicza rodzaje stosunków w ustalonej przez autora kolejności, zmieniając lub skracając w wielu wypadkach ich nazwy, ale nie zmieniając podanych przez autora przykładów. Można przypuszczać, że niektóre wyrażenia w cytowanych niżej przykładach Klemensiewicz ujął w nawias po to, by pokazać, że nie są one członami danego stosunku. Przytaczanie rozwlekłych i często niekomunikatywnych charakterystyk poszczególnych stosunków uznałem za nieuzasadnione. Celem poniższego wyliczenia jest prezentacja obrazu zależności, które brał pod uwagę uczony, ustalając zbiór znaczeń stosunkowych. Oto wykaz typów stosunków.

(1) Stosunek współwystępowania obiektów lub stanów rzeczy, np. Jan i Paweł (odwiedzą) moich i twoich krewnych i znajomych w Krakowie i w Nowej Hucie. Zwieziono z lasu kilka wozów jałowca i palono go na rynku miejskim.

(2) Stosunek alternatywy wykluczającej, np. Brat przyjdzie po nas albo zaczeka $\mathrm{w}$ domu.

(3) Stosunek przeciwstawienia, np. (Jan jest) zdolny, ale leniwy. (Pracuje) prędko, lecz niedbale. Imię było niemieckie, dusza litewska została.

(4) Stosunek porównania i wyników porównania, np. (Spotkamy się) jutro, czyli we czwartek. Żaglowce, niby stada (łabędzi... mknęły lekko ku kresom). (Jan) różnił się od kolegów. Był on dla mnie tym, czym starszy brat dla rodzeństwa. Młode rozhukane życie omijało ją, jak wzburzony potok omija zawadzający głaz.

(5) Stosunek czasowy, np. Nazajutrz rano wyruszyli (w drogę). Ledwie Sędzia zoczył papiery i ołówki, poznał rysownika. Andrzej musiał przeczekać chwilę, zanim wydostał z szatni płaszcz.

(6) Stosunek przestrzenny, np. Tamtędy prowadzi (droga). (Przechodzili) przez rzekę. Tam sięgaj, gdzie wzrok nie sięga.

(7) Stosunek wnioskowania, np. (Spotkamy się) jutro, więc w niedzielę. (Jesteś) młody, więc (mało) doświadczony.

(8) Stosunek przyczynowo-skutkowy, występujący w pięciu wariantach i realizowany za pomocą (a) okolicznika przyczyny lub wypowiedzenia przyczynowego, np. Rozpłakał się z żalu. Puścił go od siebie, gdyż nie było wtedy innej rady., (b) okolicznika skutku lub wypowiedzenia skutkowego, np. Walczyli 
do upadłego. Wczoraj z wieczora tak mnie bolało, że oka nie zmrużyłem., (c) okolicznika warunku lub wypowiedzenia warunkowego, np. W razie niepogody odłożymy (wycieczkę do niedzieli). Chciałem ten sprzęt w dziedzictwie zostawić dla dzieci, jeślibym się ożenił., (d) okolicznika przyzwolenia lub wypowiedzenia przyzwolonego, np. (Podczaszyc) mimo równość wziął (tytuł markiza). Słońce nadal szalało, choć minęło południe., (e) okolicznika celu lub wypowiedzenia celowego, np. Pójdziemy na koncert. Nauczycielka bacznie uważała, aby wszyscy zachowywali się przyzwoicie.

(9) Stosunek orzekający realizowany jako związek główny podmiotu z orzeczeniem oraz jako wypowiedzenie podmiotowe i orzecznikowe, np. Brat pisze. Słońce wschodzi. Zdawało się, że ciężkie krople kapią na podłogę. Byliśmy czymś, co się dopiero stawało.

(10) Stosunek między czynnością i jakością a ich dopełnieniem przedmiotowym, np. Piszę list. Pomagam przyjaciołom. (Piotr jest) chciwy sławy (i) żądny pochwał. (Jan okazał się) wierny zobowiązaniom.

(11) Stosunek między zależnymi czynnościami lub stanami, realizowany za pomocą wypowiedzenia dopełnieniowego, np. Duże opady i przewlekłe zimna w ciągu wiosny spowodowały, że jeszcze w maju woda stała w bruzdach. Niech się mąż pani nie trwoży, iż oddanie ziemi państwo tak bardzo zuboży.

(12) Stosunek realizowany za pomocą dopełnienia sprawcy, np. Miasto zostało zniszczone przez nieprzyjaciela.

(13) Stosunek między czynnością a jej współwykonawcą i narzędziem, np. Rozmawiam z przyjacielem. Piszę piórem.

(14) Stosunek między przedmiotem a wyróżniającą go cechą, realizowany za pomocą przydawki charakteryzującej i wypowiedzenia przydawkowego, np. siwe włosy, skórzana kurtka; Zobaczyła chłopa, który od świtu niezmordowanie szedł bruzdą.

(15) Stosunek między przedmiotem a cechą odróżniającą go od innych przedmiotów, realizowany za pomocą przydawki charakteryzującej, np. gałąź akacji, handel żelaza, brat lekarz, inwalida ślepiec, dach ze słomy.

(16) Stosunek posiadania, realizowany za pomocą przydawki przynależnościowej, np. dom ojca.

(17) Stosunek między przedmiotem a cechą związaną z tym przedmiotem, np. łodzie rybackie, moja matka, swoje zamiary.

(18) Stosunek ilości, liczby, miary i stopnia, np. do dwu godzin, piąty tydzień; (książka) bardzo się podobała. W miarę jak zbliżał się wieczór, ogarniała go gorączka.

(19) Stosunek polegający na wyznaczeniu obiektu, np. to drzewo, miasto Ateny; Kto robił inaczej, narażał się na drwiny całego miasteczka. Nie jestem tym, za co mnie masz. Ściany opowiadały obrazkami o tym, czego uczono. 
(20) Stosunek określający sposób wykonywania czynności, np. Mówił głośno. Czytał wyraźnie. Trzymając krawędź kołyski obiema rękami, pociągnąłem ją do siebie.

(21) Stosunek określający okoliczności tego, co się dzieje, np. Szukałem po ciemku wyjścia z pokoju. Wpadł do izby, ociekając wodą.

4. Definicja znaczenia stosunkowego struktury składniowej jest niejasna i nieostra. Denotacji tego terminu Klemensiewicz również nie wyznaczył na podstawie jednoznacznie określonych kryteriów. Jest to przede wszystkim spowodowane tym, że zbiór obiektów, który ma badać składnia, jest w ujęciu Klemensiewicza nie tylko wielkością rozmytą, ale wręcz niejednorodną. Nie wiadomo, co to są struktury składniowe. Klemensiewicz nie mówi, w jakiej relacji pozostają one względem takich pojęć należących do podstawowego aparatu uczonego, jak składnik i wypowiedzenie. Można przyjąć, że zespół składników i wypowiedzenie złożone są strukturami składniowymi. Trzeba w związku z tym przyjąć również, że oba te pojęcia opierają się na pojęciu stosunku syntaktycznego. Wbrew oczekiwaniom, że powinno ono należeć do pojęć najprostszych, takich, na których opiera się cała składnia, definicja stosunku syntaktycznego jest wyjątkowo nieoperatywna, nie pozwala na wykrywanie komunikowanej zależności. Por.:

Stosunek syntaktyczny jest tedy znakiem językowym tego stosunku, który uobecnia się świadomości mówiącego między składowymi przedstawieniami tworzywa wypowiedzeniowego (Klemensiewicz 1937: 75).

Nie ulega wątpliwości, że struktury składniowe są zbiorem otwartym. Ich globalnego opisu w postaci reguł łączenia jednostek semantyczno-składniowych nie zaproponował do dzisiaj, przynajmniej dla polszczyzny, nikt, choć próby takie były przedstawiane np. w GWJP (por. też Karolak 2002). Niepodobna byłoby więc ich oczekiwać od Klemensiewicza jako autora podręczników składni polskiej w połowie XX w. Jedyną podstawą wyliczenia tych, a nie innych typów znaczeń stosunkowych, które według uczonego są komunikowane przez struktury składniowe, była jego intuicja językowa i doświadczenie badacza składni. Nie ma bowiem żadnych zależności między wieloma typami wyróżnionych znaczeń. Tworzą one zbiór heterogeniczny, obejmujący wszystko to, co mieści się w składni sensu largo. Nie sposób uznać referencji frazy nominalnej (por. to drzewo), związku orzeczenia z podmiotem (por. Słońce wschodzi.), zależności między częściami jednostki leksykalnej (por. różnit się od) za znaczenie stosunkowe. Fraza nominalna wyznaczona (w terminologii Topolińskiej 1984) ilustruje akt wskazywania, a związek podmiotu z orzeczeniem akt orzekania. Nie zawiera też znaczenia stosunkowego ciąg odzwierciedlający hiponimię jednostek (np. siwe włosy) ani utworzony w wyniku wypełnienia otwieranej przez czasownik bądź przymiotnik pozycji syntaktycznej (por. przechodzili przez rzeke, pisze list, pomagam przyjaciołom, żądny sławy, chciwy pochwał, wierny 
zobowiąaniom, rozmawiam z przyjacielem). Wszystkie przykłady podaję za Klemensiewiczem (1958/1969).

$\mathrm{W}$ świetle przedstawionych argumentów skazana na niepowodzenie jest próba urzeczywistnienia myśli Klemensiewicza (ibid.: 193), by wytyczyć granicę między znaczeniem leksykalnym a znaczeniem stosunkowym. Jedyna racjonalna droga do wyodrębniania tzw. znaczeń stosunkowych polega na analizie składniowo-semantycznej ich wykładników. To one decydują o znaczeniu łączonych struktur. Nawet jeżeli w danym wypowiedzeniu wykładnik taki nie występuje, to można dokonać jego interpolacji choćby po to, żeby uznać to wypowiedzenie za reprezentujące określony typ struktury syntaktycznej. Taki tryb postępowania badawczego był stosowany we wspomnianej wcześniej GWJP.

5. Nie wiadomo, dlaczego Z. Klemensiewicz nie koncentrował uwagi na badaniu wykładników struktur syntaktycznych, a więc na przyimkach, spójnikach i zaimkach. Napisał wprawdzie kilka artykułów poświęconych jednostkom tych klas, np. o jak, choć, jeszcze (Klemensiewicz 1946, 1957, 1963b), ale na tle całego, ogromnego dorobku uczonego jest to liczba znikoma. Dopiero pod koniec życia zaproponował globalny, sumaryczny opis spójnikowych i zaimkowych wskaźników zespolenia (Klemensiewicz 1969a). Była to jednak tylko analiza formalna.

Jeżeli przyjmie się, że przyimki, spójniki, zaimki są leksemami języka polskiego, to tak samo jak czasowniki, przymiotniki czy rzeczowniki mają one swoje znaczenia leksykalne. To, że pełnią inne funkcje w systemie językowym, nie jest wystarczającym argumentem na rzecz tezy, że ich znaczenia reprezentują inny rodzaj bytu. Nie ma więc znaczeń stosunkowych obok znaczeń leksykalnych. Jednostki systemu językowego mają znaczenia leksykalne, krótko mówiąc, po prostu znaczenia. W językoznawstwie doby Klemensiewicza nie uświadamiano sobie istnienia różnicy między jednostkami poziomu przedmiotowego a jednostkami poziomu meta. Myśl, że te drugie służą komentowaniu pierwszych, zaczęła się rozpowszechniać od lat 70. XX w. (Wierzbicka 1969, 1971), a dopiero na początku XXI w. stała się aksjomatem w badaniu spójników i partykuł (Wajszczuk 1997, 2005; Grochowski 2011; Grochowski, Kisiel, Żabowska 2014).

Podstawową przyczyną tego, że w aparacie terminologicznym Klemensiewicza figurowało znaczenie stosunkowe, był fakt, że nie operował on konotacją w analizie składniowej. Na marginesie charakterystyki podmiotu psychologicznego i orzeczenia psychologicznego (Klemensiewicz 1969b: 54) odwołał się co prawda do świeżo opublikowanego wówczas artykułu Tadeusza Milewskiego (1952/1971), prezentującego teorię konotacji w strukturalizmie europejskim (w ujęciu nawiązującym do funkcji glossematycznych Louisa Hjelmsleva), ale teorii tej nie rozwijał ani nie zastosował. Milewski (ibid.: 34) w swojej charakterystyce konotacji syntagmatycznej zwracał uwagę m.in. na to, że spójniki otwierają dwa miejsca dla zdań (z wyjątkiem spójnika kopulatywnego $i$, który miejsc tych nie ogranicza składniowo). Jeszcze 
wcześniejszym niż artykuł Milewskiego źródłem teorii konotacji w językoznawstwie polskim był artykuł Jerzego Kuryłowicza (1948), przedstawiający autorską teorię dotyczącą relacji między członami konstytutywnymi grupy i zdania a ich członami określanym i określającym.

Nie ma w teorii syntaktycznej Klemensiewicza, nawet w jego Studiach syntaktycznych, istotnego dla opisu związków składniowych przeciwstawienia składników (członów) konotujących i występujących w pozycjach konotowanych oraz tych pierwszych i składników przyłączanych do nich na zasadzie dodawania (ale nie konotowanych). Brak konotacji jako narzędzia opisu struktury zdania sprawiał, że relacje między jego częściami, np. podmiotem a orzeczeniem, ujmowano w kategoriach związków zgody, rządu i przynależności, co z kolei przyczyniło się do uproszczeń zarówno w analizie składniowej, jak i w analizie zależności semantycznych. Potwierdza to literatura dotycząca m.in. związków liczebników z rzeczownikami (por. np. Bogusławski 1973a; Gruszczyński, Saloni 1978).

Wszystkie leksemy języka polskiego, bez względu na to, jakie klasy gramatyczne reprezentują, są zdolne do otwierania pozycji syntaktycznych dla innych wyrażeń. Fakt ten nie determinuje żadnych różnic między typami znaczeń leksemów. Znaczenie rzeczownika czy spójnika, czasownika czy zaimka reprezentuje ten sam rodzaj bytu, nie ma więc takich dwóch odrębnych kategorii semantycznych, jak znaczenie stosunkowe i znaczenie leksykalne. Adekwatny opis semantyczny poszczególnych leksemów nie może nie odwoływać się do konotowanych przez nie pozycji syntaktycznych. Jest to metoda badawcza dobrze znana w literaturze semantycznej i w teorii leksykografii, począwszy od lat 70. XX w. (por. np. Bogusławski 1973b). Kształtowała się w ostatniej dekadzie życia i działalności twórczej Z. Klemensiewicza. Jest więc zrozumiałe, że uczony tą metodą się nie posługiwał. W czasach Klemensiewicza nie uświadamiano sobie tego, że wzajemne relacje między słownikiem a gramatyką są podstawą badania nie tylko formalnych, ale przede wszystkim semantycznych właściwości jednostek leksykalnych. Świadomość tych zależności i metod ich badania rozpowszechniła się dopiero w latach późniejszych (por. np. Wajszczuk 2011).

\section{Literatura}

Ajdukiewicz K., 1960, O znaczeniu wyrażeń, [w:] idem, Język i poznanie, t. I: Wybór pism $z$ lat 1920-1939, Warszawa, s. 102-136.

Arystoteles, 1975, Kategorie i Hermeneutyka $z$ dodaniem Isagogi Porfiriusza, thum. i oprac. K. Leśniak, Warszawa.

BogusŁaWsKi A., 1973a, Nazwy pospolite przedmiotów konkretnych i niektóre właściwości ich form liczbowych i połaczeń z liczebnikami w jezzku polskim, [w:] Z. Topolińska, M. Grochowski (red.), Liczba, ilość, miara. Materiały Konferencji Naukowej w Jadwisinie, 11-13 maja 1972 r., Wrocław - Warszawa, s. 7-35.

BogusŁawski A., 1973b, O analizie semantycznej, „Studia Semiotyczne” IV, s. 47-70. 
Dzıoвкоwsкi B., 2016, Teorie znaczenia, [w:] J. Odrowąż-Sypniewska (red.), Przewodnik po filozofii języka, Kraków, s. 19-66.

Frege G., 1977, Pisma semantyczne, tłum. i oprac. B. Wolniewicz, Warszawa.

GóRnY W., 1962, Zestawienie - czy tylko kategoria składniowa? „Pamiętnik Literacki” LIII, S. $181-193$.

Grabarczyк P., 2018, W poszukiwaniu teorii znaczenia. Próby eksplikacji pojęcia znaczenia $w$ filozofii XX wieku, Łódź.

Grochowski M., 2011, Zenona Klemensiewicza koncepcja składnika wypowiedzenia $w$ świetle współczesnej składni semantycznej, [w:] R. Majkowska, E. Fijałek (red.), Zenon Klemensiewicz 1891-1969. Materiały z posiedzenia naukowego $w$ dniu 19 czerwca 2009 r., Kraków, s. 47-58.

Grochowski M., Kisiel A., Żabowska M., 2014, Słownik gniazdowy partykuł polskich, Kraków.

Gruszczyński W., SALONi Z., 1978, Składnia grup liczebnikowych we współczesnym języku polskim, „Studia Gramatyczne” II, s. 17-42.

GWJP: M. Grochowski, S. Karolak, Z. Topolińska, Gramatyka współczesnego języka polskiego. Składnia, Warszawa 1984.

KarolaK S., 2002, Podstawowe struktury składniowe języka polskiego, Warszawa.

KlemensiewiCZ Z., 1937, Składnia opisowa współczesnej polszczyzny kulturalnej, Kraków.

KlemensiewiCZ Z., 1946, O wyrazie jak z funkcja wskaźnika zespolenia zdań złożonych w gwarach ludowych, [w:] Inter arma. Zbiór prac ofiarowanych prof. Kazimierzowi Nitschowi w siedemdziesiąta rocznicę urodzin (1 II 1944) przez przyjaciót, kolegów i uczniów, Kraków, s. 5-11.

KLEMENSIEWICZ Z., 1957, O rzadszych funkcjach syntaktycznych wyrazu choć i podobnych, „Język Polski” XXXVII, s. 261-268.

KLEMENSIEwiCZ Z., 1958/1969, O znaczeniu stosunkowym struktur składniowych, „Biuletyn Polskiego Towarzystwa Językoznawczego” XVII, s. 3-18; przedruk w: Z. Klemensiewicz, Ze studiów nad językiem i stylem, Warszawa 1969, s. 186-199.

Klemensiewicz Z., 1963a, Zarys składni polskiej, Warszawa.

Klemensiewicz Z., 1963b, O znaczeniu i syntaktycznym użyciu wyrazu jeszcze, [w:] T. Milewski, J. Safarewicz, F. Sławski (red.), Studia linguistica in honorem Thaddaei Lehr-Spławiński, Warszawa, s. 363-367.

KLemensiewicz Z., 1967, Studia syntaktyczne, Wrocław.

Klemensiewicz Z., 1969a, Studia syntaktyczne, cz. II, Wrocław.

KlemensiewiCZ Z., 1969b, Problematyka psychologicznej interpretacji zdania gramatycznego, [w:] idem, Ze studiów nad językiem i stylem, Warszawa, s. 43-59.

KuRYŁOWICZ J., 1948, Les structures fondamentales de la langue: groupe et proposition, „Studia Philosophica” III, s. 203-209.

Lewicki A.M., 1971, Wstęp, [w:] idem (red.), Problemy składni polskiej. Studia, dyskusje, polemiki z lat 1945-1970, Warszawa, s. 5-15.

LewiCKi A.M., 2001, Językoznawstwo polskie w XX wieku, [w:] J. Bartmiński (red.), Współczesny język polski, wyd. 2, Lublin, s. 619-656.

Locke J., 1955, Rozważania dotyczące rozumu ludzkiego, tłum. B. Gawecki, Warszawa.

Maciaszex J., 2008, Znaczenie, prawda, przekonania. Problematyka znaczenia $w$ filozofii języka, Łódź. 
Milewski T., 1952/1971, Stanowisko składni w obrębie językoznawstwa, „Biuletyn Polskiego Towarzystwa Językoznawczego" XI, s. 74-92; przedruk w: A.M. Lewicki (red.), Problemy składni polskiej. Studia, dyskusje, polemiki z lat 1945-1970, Warszawa 1971, s. 17-36.

TopolińsKa Z., 1984, Składnia grupy imiennej, [w:] GWJP, s. 301-389.

WAjszczuk J., 1997, System znaczeń w obszarze spójników polskich. Wprowadzenie do opisu, Warszawa.

WajszczuK J., 2005, O metatekście, Warszawa.

Wajszczuk J., 2011, Oprócz - jaka to część mowy? Rozmyślania na marginesie Andrzeja Bogusławskiego studium o znaczeniu rosyjskiego krome, „Poradnik Językowy” nr 1, s. 96-109.

Wierzbicka A., 1969, Dociekania semantyczne, Wrocław.

Wierzbicka A., 1971, Metatekst w tekście, [w:] M.R. Mayenowa (red.), O spójności tekstu, Wrocław, s. 105-121.

ZARon Z., 2002, Wypowiedzenie, zdanie, wypowiedź. Regulacje terminologiczne, „Slavistički Studii” 10, s. 151-166.

Ż̀воwsка M., 2017, Makroskładnia - wypowiedzeniowe struktury syntaktyczne, „Linguistica Copernicana” 14, s. 71-87, [on-line:] http://dx.doi.org/10.12775/LinCop.2017.005.

\section{The Notion of Meaning and Its Scope in Zenon Klemensiewicz's Conception of Syntax Summary}

The goal of the paper is to reconstruct and analyse Z. Klemensiewicz's views on the place that so-called 'relative meaning' occupied in his conception of syntax. Klemensiewicz distinguished 21 types of relative meanings and gave examples of their grammatical and lexical markers. His works, reminded in this paper after nearly half a century from their publication, are treated as documents of historical value. 